\title{
The Extent of Disclosure of Different Components of Disclosure Index: A Study on Commercial Banks in Bangladesh
}

\section{Taposh Kumar Neogy ${ }^{1 *}$, Alim Al Ayub Ahmed ${ }^{2}$}

${ }^{1}$ Assistant Professor (Accounting), Institute of Business Administration (IBA), Rajshahi (under National University), BANGLADESH

${ }^{2}$ Assistant Professor (Accounting), Faculty of Business, ASA University Bangladesh, Dhaka, BANGLADESH

*Corresponding Contact:

Email: neogyais@gmail.com

Cell Phone: +8801719711916

\begin{abstract}
This discussion highlights the disclosure score of different components of disclosure index of the selected state-owned commercial banks in Bangladesh. The annual reports of the selected commercial banks were analyzed to determine the extent of disclosure score of different components of disclosure index which contained the items of information included in the disclosure index of the selected commercial banks during the period under study. An index of disclosure has constructed less than seven heading to measure the extent of disclosure score of different components of disclosure index such as company profile items, corporate structure items, accounting policy items, balances sheet assets items, balance sheet liabilities items, income statement debit items and income statement credit items. This study shows that the disclosure score of different components of disclosure index is satisfactory and there was significant and non significant difference in disclosure score of different components of disclosure index between the selected state-owned commercial banks in different years.
\end{abstract}

Keywords: Financial Statements, Items of Disclosure, Disclosure Index, Commercial Banks, Bangladesh

\section{INTRODUCTION}

Disclosure means communicating relevant and reliable information for the interested stakeholders to make effective decision making process. Disclosure in financial reporting is the presentation of necessary information related to a business entity to meet the needs of different users. The users group needs accounting information to decide in their respective field of interest. For example the investor group requires information regarding investment feasibility. The creditors group requires information to form judgment regarding the credit worthiness of the borrows. Thus the needs for information of the different groups vary. So, a 
company has to meet the demand of users but it is a difficult task to meet the demand of all users because there are cost constraints. So, in the light of foregoing discussion disclosure means disseminating relevant financial and non financial information of a business enterprise to the audience of interest. Disclosure is an important variable in any measurement of accounting quality together with such characteristics as measurement method; presentation and timeliness of reporting and can take a number of different forms. Normally disclosure might be considered in relation to the annual report but there are a number of other routes by which company information is communicated (Marston and Robson, 1997). Disclosure means the effective communication of meaningful information for the satisfaction of different stakeholders. In Bangladesh disclosure practices are prescribed by the Companies Act, 1994, Securities and Exchange Rules, 1987, Income Tax ordinance, 1984, the Accounting Standards and Financial Reporting Standards adopted by the Institute of Chartered Accountants of Bangladesh (ICAB). Proper disclosure of relevant information in the financial statements of a company is of great importance, since the members of the company as well as other parties; make most of their appraisals regarding the company on the basis of such statements. Annual financial statements should, therefore, disclosure relevant financial information clearly and accurately. Disclosure in financial reporting is the presentation of information necessary for the optimum operation of efficient capital markets. This implies that sufficient information should be presented to permit the prediction of future dividend trends and variability and the co variability of future returns with the market. Emphasis should be placed on the preferences of sophisticated investors and financial analysis. However, all investors need information to evaluate the relative risks of individual firms in order to obtain diversified portfolios and combination of investment that meet individual risk preferences. Creditors and governmental agencies generally have the power to obtain additional information for their needs. The ultimate objective of disclosure is to communicate timely, reliable, and material information which is useful to the users of annual reports, in an intelligible form (Agarwal, 1995). Disclosure is an important requirement in the preparation of financial statements. Disclosure is defined as "a clear showing of a fact or condition on a balance sheet or other financial statements, in foot notes applicable thereto, or in an audit report". It enables the interested parties to gain an insight into the functioning of an organization. In Bangladesh, disclosures to be made by the companies registered under the Companies Act are governed by the said Act. (Hye, 1986). In the corporate sector, accountability and transparency is the slogan of the day. Communication of economic information to the interest groups is assuming greater importance due to increasing control of economic activities by the corporate sector. Adequate disclosure is the most important way by which we can meet the information need of diverse interest groups of nation decision making. Meaningful communication through disclosure in financial statement also ensures transparency and accountability (Akter and Hoque, 1993).

The banks which perform all kinds of banking activities and generally finance trade and commerce are called commercial banking. A commercial bank is a profit-seeking business firm, dealing in money and credit. Commercial banks are the most dominant financial institutions in the domain of commerce and industry. Now-a-days, the function of bank is not limited within the same geographical limit of any country. Due to globalization and free market economy, this industry becomes the most powerful financial intermediary in the field of trade and commerce and is facing severe competition in any country. Banking sector provides facilities to rebuild the agriculture, industry as well as service sector by allowing loans, credit and advances. It creates an opportunity of lucrative jobs for its better employment structure. Government also in most cases depends on banking sector to meet its emergency requirements (Alam, 2013). The banking sector of Bangladesh comprises four categories of scheduled banks. These are state-owned commercial banks (SCBs), state- 
owned development financial institutions (DFIs), private commercial banks (PCBs) and foreign commercial banks (FCBs). The study includes two state owned commercial banks Janata Bank Limited and Agrani Bank Limited. Janata Bank Limited took over the business, assets, liabilities, right, power, privilege and obligation of erstwhile Janata bank (emerged as a Nationalized Commercial Bank in 1972), pursuant Bangladesh Bank Nationalization Order 1972 (P.O. No. 26 of 1972) on a going concern basis through a vendor agreement signed between the Ministry of Finance, People's Republic of Bangladesh on behalf of Janata Bank and the Board of Directors on behalf of Janata Bank Limited on 15 November 2007 with a retrospective effect from 1 July 2007. Again, Agrani Bank Limited (ABL) was incorporated as a State Owned Commercial Bank on 17 May 2007 under the Companies Act 1994. Agrani Bank emerged as a Nationalized Commercial Bank following the Bangladesh Banks (Nationalization) Order 1972 vides President's Order No. 26 of 1972. On a going concern basis ABL took over the business, assets, liabilities, rights and obligations of Agrani Bank through a vendor's agreement signed on 15 November 2007 between the Ministry of Finance of the People's Republic of Bangladesh \& the Board of Directors of ABL with retrospective effect from 1 July 2007.

\section{ObJective Of The Study}

The main objective of the study is to know the extent of disclosure score of the different components of disclosure index of the selected state-owned commercial banks in Bangladesh for the period from 2009 to 2013.

\section{Methodology of the Study}

Research methodology is very much essential to evaluate the research problem systematically. At present four state-owned commercial banks are working in Bangladesh in which researcher selected two state-owned commercial banks such as Janata Bank Limited (here in after Sample \# 1) and Agrani Bank Limited (here in after Sample \# 2) for the present research study. The selection of the banks is based on the convenience in data collection. The study is mainly conducted on the basis of secondary data and the secondary data have been collected from journals, reports, economic review and audited annual reports of the selected state-owned commercial banks. The various statistical tools like average, standard deviation, coefficient of variation and T-test used for analyzing the collected data.

\section{Hypothesis OF THE STUdy}

Based on the review of related literature, the following hypotheses have developed and tested:

Ho1: There is no significant difference in disclosure scores of the selected state-owned commercial banks regarding the company profile items.

Ho2: There is no significant difference in disclosure scores of the selected state-owned commercial banks regarding the corporate structure items.

Ноз: There is no significant difference in disclosure scores of the selected state-owned commercial banks regarding the accounting policy items.

Ho4: There is no significant difference in disclosure scores of the selected state-owned commercial banks regarding the balance sheet assets items.

Ho5: There is no significant difference in disclosure scores of the selected state-owned commercial banks regarding the balance sheet liabilities items. 
Ho6: There is no significant difference in disclosure scores of the selected state-owned commercial banks regarding the income statement debit items.

Ho7: There is no significant difference in disclosure scores of the selected state-owned commercial banks regarding the income statement credit items.

\section{CONSTRUCTION OF DISCLOSURE INDEX}

A disclosure index has been constructed to find out the pattern of disclosure score by the selected state-owned commercial banks. There are two types of disclosure indices such as weighted index and un-weighted index. Researcher has constructed un-weighted index using dichotomous scale for the purpose of the present research study. For constructing unweighted index researcher has been selected 98 items both voluntary and mandatory under seven headings such as the company profile items, corporate structure items, accounting policy items, balance sheet assets items, balance sheet liabilities items, income statement debit items and income statement credit items. Each item of information has been given a score of zero if it is not disclosed and a score of one has been awarded if that item is disclosed by the selected state-owned commercial banks in the annual reports. Then the total of raw score is divided by the total number of items and multiplied by 100 to get the disclosure percentage. The following table clearly shows the 98 items of different part of disclosure index:

Various Items of Disclosure Index

\begin{tabular}{|l|c|c|}
\hline Various Components & No. of Items & Percentage (\%) \\
\hline 1. Company Profile Items & 11 & 11.22 \\
\hline 2. Corporate Structure Items & 15 & 15.30 \\
\hline 3. Accounting Policy Items & 13 & 13.27 \\
\hline 4. Balance Sheet Assets Items & 19 & 19.39 \\
\hline 5. Balance Sheet Liabilities Items & 16 & 16.33 \\
\hline 6. Income Statement Debit Items & 11 & 11.22 \\
\hline 7. Income Statement Credit Items & 13 & 13.27 \\
\hline Total & 98 & 100 \\
\hline
\end{tabular}

(Source: Disclosure Checklist)

The total disclosure scores of the selected state-owned commercial banks measured by the un-weighted disclosure method are as follows:

$$
T D=\sum_{i=1}^{n} d i
$$

Where,

$\mathrm{TD}=$ Total Disclosure

$\mathrm{d}=1$ if the item di is disclosed

$0=$ if the item di is not disclosed

$\mathrm{n}=$ number of items

\section{Findings AND TESTING Hypotheses OF THE StUdy}

Year wise disclosure scores of company profile items: Ho1: There is no significant difference in disclosure scores of the selected state-owned commercial banks regarding the company profile items. 
Table 1: Table showing the disclosure scores of the selected state-owned commercial banks regarding company profile items during the years from 2009 to 2013

\begin{tabular}{|l|c|c|c|c|}
\hline Year & Sample \# 1 (\%) & Sample \# 2 (\%) & $\mathrm{t}$ values & SL \\
\hline 2009 & 81.82 & 72.73 & & \\
\cline { 1 - 3 } 2010 & 90.91 & 90.91 & & \\
\cline { 1 - 3 } 2011 & 90.91 & 90.91 & & \\
\cline { 1 - 3 } 2012 & 90.91 & 90.91 & & \multirow{2}{*}{0.374} \\
\cline { 1 - 3 } 2013 & 90.91 & 90.91 & & \\
\cline { 1 - 3 } Avg. & 89.09 & 87.27 & & \\
\cline { 1 - 3 } SD & 4.07 & 8.13 & & \\
\hline CV & 4.56 & 9.32 & & \\
\hline
\end{tabular}

(Source: Audited Annual Reports of the Selected Commercial Banks)

Table 1 shows the year-wise disclosure scores regarding company profile items of the selected state-owned commercial banks during the period under study. The average disclosure scores of company profile items are $89.09 \%$ and $87.27 \%$ respectively. The standard deviation of company profile items are 4.07 and 8.13 and the coefficient of variation of company profile items are 4.56 and 9.32 respectively. It has been seen that the Sample \# 1 more disclosed of company profile items than Sample \# 2 during the period under study. Table also shows that the selected commercial banks disclose the company profile items almost same. In order to see whether there is any significant difference in disclosure scores of the selected commercial banks regarding the company profile items and researcher conducted paired sample $t$ test using SPSS. The result shows that $t$ value is 1.000 which is significant at 0.374 levels. This indicates that there is no significant difference between the disclosure scores regarding the company profile items of the selected commercial banks. From the foregoing discussion it is evident that the disclosure scores of the company profile items of the selected commercial banks are satisfactory.

Year wise disclosure scores of corporate structure items: Ho2: There is no significant difference in disclosure scores of the selected state-owned commercial banks regarding the corporate structure items.

Table 2: Table showing the disclosure scores of the selected state-owned commercial banks regarding the corporate structure items during the years from 2009 to 2013

\begin{tabular}{|c|c|c|c|c|}
\hline Year & Sample \# 1 (\%) & Sample \# 2 (\%) & t values & SL \\
\hline 2009 & 73.33 & 73.33 & \multirow{8}{*}{1.000} & \multirow{8}{*}{0.374} \\
\hline 2010 & 73.33 & 73.33 & & \\
\hline 2011 & 86.67 & 73.33 & & \\
\hline 2012 & 86.67 & 86.67 & & \\
\hline 2013 & 86.67 & 86.67 & & \\
\hline Avg. & 81.33 & 78.67 & & \\
\hline SD & 7.31 & 7.31 & & \\
\hline$C V$ & 8.98 & 9.29 & & \\
\hline
\end{tabular}

(Source: Audited Annual Reports of the Selected Commercial Banks)

Table 2 shows the year-wise disclosure scores of corporate structure items of the selected state-owned commercial banks during the period under study. The Table shows that the 
mean of disclosure scores of corporate structure items are $81.33 \%$ and $78.67 \%$ respectively. The standard deviation of corporate structure items are 7.31 and 7.31 and the coefficient of variation of corporate structure items are 8.98 and 9.29 respectively. The Table also shows that the disclosure scores of corporate structure items of Sample \# 1 is greater than Sample \# 2 during the period under study but the difference of disclosing corporate structure items between the selected commercial banks are poor. In order to see whether there is any significant difference in disclosure scores of corporate structure items of the selected commercial banks researcher conducted paired sample $t$ test using SPSS. The result shows that $\mathrm{t}$ value is 1.000 which is significant at 0.374 levels. This indicates that there is no significant difference in disclosure scores of corporate structure items of the selected commercial banks. From the previous discussion it is evident that the disclosure scores of the corporate structure items of the selected commercial banks are satisfactory.

Year wise disclosure scores regarding accounting policy items: Ho3: There is no significant difference in disclosure scores of the selected state-owned commercial banks regarding the accounting policy items.

Table 3: Table showing the disclosure scores of the selected state-owned commercial banks regarding the accounting policy items during the years from 2009 to 2013

\begin{tabular}{|l|c|c|c|c|}
\hline Year & Sample \# 1 (\%) & Sample \# 2 (\%) & t values & SL \\
\hline 2009 & 76.92 & 69.23 & & \\
\cline { 1 - 3 } 2010 & 84.62 & 69.23 & & \\
\cline { 1 - 3 } 2011 & 84.62 & 76.92 & & \\
\cline { 1 - 3 } 2012 & 84.62 & 76.92 & \multirow{3}{*}{0.034} \\
\cline { 1 - 3 } 2013 & 84.62 & 84.62 & & \\
\cline { 1 - 3 } Avg. & 83.08 & 75.38 & & \\
SD & 3.44 & 6.44 & & \\
\hline CV & 4.14 & 8.54 & & \\
\hline
\end{tabular}

(Source: Audited Annual Reports of the Selected Commercial Banks)

Table 3 shows the year-wise disclosure scores of accounting policy items of the selected stateowned commercial banks during the period under study. The mean of disclosure scores of accounting policy items are $83.08 \%$ and $75.38 \%$ respectively. The standard deviation of accounting policy items of the selected commercial banks are 3.44 and 6.44 and the coefficient of variation of accounting policy items of the selected commercial banks are 4.14 and 8.54 respectively. This Table indicates that the Sample \# 1 disclosure scores of accounting policy items are greater than Sample \# 2 during the period under study. In order to see whether there is any significant difference in disclosure scores of accounting policy items of the selected commercial banks researcher conducted paired sample t test using SPSS. The result shows that $\mathrm{t}$ value is 3.163 which is significant at 0.034 levels. This indicates that there is significant difference in disclosure scores of accounting policy items of the selected commercial banks. The Table also shows that the disclosure scores of accounting policy items of the selected commercial banks are satisfactory during the period under study.

Year wise disclosure scores of balance sheet assets items: Ho4: There is no significant difference in disclosure scores of the selected state-owned commercial banks regarding the balance sheet assets items. 
Table 4: Table showing the disclosure scores of the selected state-owned commercial banks regarding the balance sheet assets items during the years from 2009 to 2013

\begin{tabular}{|l|c|c|c|c|}
\hline Year & Sample \# 1 (\%) & Sample \# 2 $(\%)$ & $t$ values & SL \\
\hline 2009 & 68.42 & 68.42 & & \\
\cline { 1 - 3 } 2010 & 68.42 & 68.42 & & \\
\cline { 1 - 3 } 2011 & 73.68 & 68.42 & & \\
\cline { 1 - 3 } 2012 & 73.68 & 73.68 & & \multirow{2}{*}{0.178} \\
\cline { 1 - 3 } 2013 & 78.95 & 73.68 & & \\
\cline { 1 - 3 } Avg. & 72.63 & 70.52 & & \\
\cline { 1 - 3 } SD & 4.40 & 2.88 & & \\
\hline CV & 6.06 & 4.09 & & \\
\hline
\end{tabular}

(Source: Audited Annual Reports of the Selected Commercial Banks)

Table 4 shows the year-wise disclosure scores of balance sheet assets items of the selected state-owned commercial banks during the period under study. The mean of disclosure scores of balance sheet assets items of the selected commercial banks are $72.63 \%$ and $70.52 \%$ respectively. Sample \# 1 disclosed of balance sheet assets items more than Sample \# 2. The standard deviation of balance sheet assets items of the selected companies are 4.40 and 2.88 and the coefficient of variation of balance sheet assets items of the selected commercial banks are 6.06 and 4.09 respectively. This means that the disclosure scores varied over the years under study in respect of balance sheet asset items between the two selected commercial banks. In order to see whether there is any significant difference in disclosure scores of balance sheet assets items of the selected commercial banks researcher conducted paired sample $t$ test using SPSS. The result shows that $t$ value is 1.633 which is significant at 0.178 levels. This indicates that there is no significant difference in disclosure scores of balance sheet assets items of the selected commercial banks during the period under study. From the above discussion it is apparent that the average disclosure scores of the balance sheet assets items of Sample \# 1 and Sample \# 2 are satisfactory during the period under study.

Year wise disclosure scores regarding the balance sheet liabilities items: Ho5: There is no significant difference in disclosure scores of the selected state-owned commercial banks regarding the balance sheet liabilities items.

Table 5: Table showing the disclosure scores of the selected state-owned commercial banks regarding the balance sheet liabilities items during the years from 2009 to 2013

\begin{tabular}{|l|c|c|c|c|}
\hline Year & Sample \# 1 (\%) & Sample \# 2 (\%) & t values & SL \\
\hline 2009 & 62.50 & 62.50 & & \\
\cline { 1 - 3 } 2010 & 62.50 & 62.50 & & \\
\cline { 1 - 3 } 2011 & 62.50 & 62.50 & & \\
\hline 2012 & 68.75 & 62.50 & \multirow{3}{*}{1.000} & \multirow{2}{*}{0.374} \\
\hline 2013 & 68.75 & 68.75 & & \\
\cline { 1 - 3 } Avg. & 65.00 & 63.75 & & \\
\cline { 1 - 3 } SD & 3.42 & 2.80 & & \\
\cline { 1 - 3 } CV & 5.27 & 4.38 & & \\
\hline
\end{tabular}

(Source: Audited Annual Reports of the Selected Commercial Banks) 
Table 5 shows the year-wise disclosure scores of balance sheet liabilities items of the selected commercial banks during the period under study. The Table shows that the mean of disclosure scores of balance sheet liabilities items of the selected commercial banks are $65.00 \%$ and $63.75 \%$ respectively. It is praiseworthy that balance sheet liabilities items have been disclosed more by Sample \# 1 than Sample \# 2 during the period under study. The standard deviations of balance sheet liabilities items of the selected commercial banks are 3.42 and 2.80 and the coefficient of variation of balance sheet liabilities items of the selected commercial banks are 5.27 and 4.38 respectively. In order to see whether there is any significant difference in disclosure scores of balance sheet liabilities items of the selected commercial banks researcher conducted paired sample t test using SPSS. The result shows that $\mathrm{t}$ value is 1.000 which is significant at 0.374 levels. This indicates that there is no significant difference in disclosure scores of balance sheet liabilities items of the selected commercial banks. The Table also highlights that the disclosure scores of balance sheet liabilities items of Sample \# 1 and Sample \# 2 are satisfactory during the period under study.

Year wise disclosure scores regarding income statement debit items: Ho6: There is no significant difference in disclosure scores of the selected state-owned commercial banks regarding the income statement debit items.

Table 6: Table showing the disclosure scores of the selected state-owned commercial banks regarding the income statement debit items during the years from 2009 to 2013

\begin{tabular}{|c|c|c|c|c|}
\hline Year & Sample \# 1 (\%) & Sample \# 2 (\%) & t values & SL \\
\hline 2009 & 86.36 & 79.55 & \multirow{8}{*}{2.060} & \multirow{8}{*}{0.108} \\
\hline 2010 & 86.36 & 81.82 & & \\
\hline 2011 & 86.36 & 86.36 & & \\
\hline 2012 & 88.64 & 86.36 & & \\
\hline 2013 & 88.64 & 88.64 & & \\
\hline Avg. & 87.27 & 84.55 & & \\
\hline SD & 1.25 & 3.73 & & \\
\hline $\mathrm{CV}$ & 1.43 & 4.42 & & \\
\hline
\end{tabular}

(Source: Audited Annual Reports of the Selected Commercial banks

Table 6 shows the year-wise disclosure scores of income statement debit items of the selected stateowned commercial banks during the period under study. The mean of disclosure scores of income statement debit items of the selected commercial banks are $87.27 \%$ and $84.55 \%$ respectively. From the above Table it is observed that Sample \# 1 disclosed of income statement debit items more than Sample \# 2. The standard deviation of income statement debit items of the selected commercial banks are 1.25 and 3.73 and the coefficient of variation of income statement debit items of the selected commercial banks are 1.43 and 4.42 respectively. This means that the value of SD and CV in disclosure scores of Sample \# 1 over the years under study is in respect of income statement debit items lowest than that of Sample \# 2. In order to see whether there is any significant difference in disclosure scores of income statement debit items of the selected commercial banks researcher conducted paired sample $t$ test using SPSS. The result shows that $t$ value is 2.060 which is significant at 0.108 levels. This indicates that there is no significant difference in disclosures scores of income statement debit items of the selected commercial banks during the period under study. The Table also presents that the average disclosure scores of income statement debit items of the selected commercial banks are satisfactory during the period under study. 
Year wise disclosure scores regarding income statement credit items: Ho7: There is no significant difference in disclosure scores of the selected state-owned commercial banks regarding the income statement credit items.

Table 7: Table showing the disclosure scores of the selected state-owned commercial banks regarding the income statement credit items during the years from 2009 to 2013

\begin{tabular}{|c|c|c|c|c|}
\hline Year & Sample \# 1 (\%) & Sample \# 2 (\%) & t values & SL \\
\hline 2009 & 69.23 & 69.23 & \multirow{8}{*}{-1.000} & \multirow{8}{*}{0.374} \\
\hline 2010 & 69.23 & 76.92 & & \\
\hline 2011 & 76.92 & 76.92 & & \\
\hline 2012 & 76.92 & 76.92 & & \\
\hline 2013 & 76.92 & 76.92 & & \\
\hline Avg. & 73.84 & 75.38 & & \\
\hline SD & 4.21 & 3.44 & & \\
\hline $\mathrm{CV}$ & 5.70 & 4.56 & & \\
\hline
\end{tabular}

(Source: Audited Annual Reports of the Selected Commercial Banks)

Table 7 shows the year-wise disclosure scores of income statement credit items of the selected state-owned commercial banks during the period under study. The mean of disclosure scores of income statement credit items of the selected commercial banks are $73.84 \%$ and $75.38 \%$ respectively which have been found during the period under study. The standard deviation of income statement credit items of the selected commercial banks are 4.21 and 3.44 and the coefficient of variation of income statement credit items of the selected commercial banks are 5.70 and 4.56 respectively during the period under study which is an indication that the disclosure scores of income statement credit items are not same of the two sample commercial banks during the period under study. In order to see whether there is any significant difference in disclosure scores of income statement credit items of the selected commercial banks researcher conducted paired sample $t$ test using SPSS. The result shows that $t$ value is -1.000 which is significant at 0.374 levels. This indicates that there is no significant difference in disclosure scores of income statement credit items of the selected commercial banks during the period under study. This Table shows that the disclosure scores of income statement credit items of Sample \# 2 is greater than that of Sample \# 1. From the previous discussion it is apparent that the average disclosure scores of the income statement credit items of the selected commercial banks are satisfactory during the period under study.

\section{CONCLUSION}

The commercial bank is the most important financial institution in Bangladesh and it's closely related with the economic development of Bangladesh. At present commercial banks is on of the most dynamic business sector in Bangladesh. The roles of commercial banks especially state-owned commercial banks are very significant for improving the economical condition and the standard of living people. This discussion highlights on the measurement and analysis of the extent of the disclosure scores of different components of the disclosure index of the selected state-owned commercial banks during the period under study. Un-weighted disclosure index has been constructed for this purpose which contains 98 items of information both mandatory and voluntary under seven headings. The average disclosure scores of different components of disclosure index are satisfactory and there was 
significant and non significant difference in disclosure scores of different components of discourse index of the selected commercial banks during the period under study. The information that is produced through preparing the different financial statements like income statement, balance sheet, owners' equity statement, cash flow statement and others statement disclose in annual report of the selected commercial banks for the users and the users of information desire that the management publish annual reports at the end of every accounting period that should be relevant and reliable so that they take sound decision according to their needs for fulfilling the various goals. The management of commercial banks is responsible for providing and disclosing the correct, relevant and reliable information for the interested users. So, the management of commercial banks should pay attention for preparing the different financial statements. The various Accounting Standards, the Companies Act 1994, the Banking Companies Act 1991, Bangladesh Banks Orders and Circulars and other provisions should be made mandatory for preparing and presenting the all necessary information. The selected commercial banks should ensure the transparency of information disclose in financial statements shown in the annual reports. Disclosure of adequate information is the most important thing for taking sound decision. So, disclosure of information should be more timely and well structured for various interested users so that they can make effective and dynamic decisions.

\section{REFERENCES}

Agarwal, (1995), "Disclosure in Company Accounts", Hind Law Publishers cited in Maleque, et. al., (2010), "Financial Disclosure in Corporate Annual Reports: A Survey of Selected Literature", Journal of the Institute of Bangladesh Studies, Vol., 33, pp. 113-132.

Ahmed AA and Dey MM. 2009. BANK LOAN OFFICERS' PERCEPTIONS OF CORPORATE FINANCIAL DISCLOSURE IN THE BANKING SECTOR OF BANGLADESH: AN EMPIRICAL ANALYSIS In:CIIT, ed. CIIT Proceedings 2nd CBRC. Lahore, Pakistan: COMSATS Institute of Information Technology.

Ahmed AA and Dey MM. 2011. Accounting Disclosure Scenario: An Empirical Study of the Banking Sector of Bangladesh Accounting \& Management Information Systems, 9.

Ahmed AA and Siddique MN. 2013. Internet Banking Espousal in Bangladesh: A Probing Study Engineering International, 1, 40-47.

Ahmed AA, Khan W and Hossain MS. 2011. Reporting Practice of Accounting Disclosure on Changes in Listed Companies of Bangladesh ASA University Review, 5, 83-96.

Ahmed AA. 2009. Measurement and Analysis of the Extent of Timeliness in Corporate Annual Reports of Banking Sector in Bangladesh Development Compilation, 1, 45-56.

Ahmed AA. 2009. THE EFFECT OF TIMELINESS REGULATION OF CORPORATE FINANCIAL REPORTING: EVIDENCE FROM BANKING SECTOR OF BANGLADESH Accounting and Management Information Systems, 8, 216 - 235.

Ahmed AA. 2012. Disclosure of Financial Reporting and Firm Structure as a Determinant: A Study on the Listed Companies of DSE ASA University Review, 6, 43-60.

Ahmed, A. A. A. (2009), "Compliance of Financial Disclosure in Corporate Annual Reports of Banking Sector of Bangladesh", Published Ph. D Dissertation, Rajshahi University.

Akter, M. and Hoque, M. (1993), Disclosure Practices in Bangladesh: A Case Study of the Banking Sector, Dhaka University Journal of Business Studies, Vol. 14(2), pp. 29-42.

Alam, M. J. (2013), “Compliance with Accounting Standards in Financial Reporting of Commercial Banks in Bangladesh", unpublished Ph. D Dissertation, Rajshahi University.

Audited Annual Reports of Selected state-owned Commercial Banks during the years from 2009 to 2013.

Cooke, T. E. (1992), “The Impact of Size, Stock Market Listing and Industry Type on Disclosure in the Annual Reports of Japanese Listed Corporations", Accounting and Business Research, Vol. 22, no. 87, pp. 229-237.

Hendriksen, (1973), "Accounting Theory", Richard D. Irwin, Inc., U.S.A 
Hossain, M. A. and Hossain M. M. (2010) “A Review of Corporate Financial Reporting and Regulations in Bangladesh", BUBT Journal, Vol. 3 (January - December), pp. 175-187.

Hye, M. A. (1986), "Disclosure of Accounting Policies and Its Current Status in Bangladesh", the Cost and Management, May-June, pp. 5-10.

Islam, M. K. S. (2000), Qualitative Characteristics of Financial Disclosure of the Commercial Banks in Bangladesh, Journal of the Institute of Bangladesh Studies, University of Rajshahi Volume 23, pp. 187-201.

Marston, C. and Robson, P. (1997), "Financial Reporting in India: Change in Disclosure over the Period 1982 to 1990", Asia-Pacific Journal of Accounting, June, pp. 109-140.

Neogy, T. K. (2013), “Disclosure Practices of Mobile Telecommunication Companies with Special Reference to Grameenphone Ltd.", Global Disclosure of Economics and Business, Volume 2, No. 1, pp. 61-75.

Nurunnabi, M. and Hossain, M.A. (2012) "The voluntary disclosure of internet financial reporting (IFR) in an emerging economy: a case of digital Bangladesh", Journal of Asia Business Studies, Vol. 6 Iss: 1, pp.17 - 42.

Pramanik, M. A. R. and Islsm, M. K. S. (1999), Disclosure of Accounting Policies: A Study of the Commercial Banks in Bangladesh, Thoughts on Economics, Vol. 9, No. 1 \& 2, January - June, pp. 49-67.

Rouf MA, Hasan MS and Ahmed AA. 2014. Financial Reporting Practices in the Textile Manufacturing Sectors of Bangladesh ABC Journal of Advanced Research, 3, 57-67.

Siddique, M. A. B. and Raboul, M. R. (2010) Disclosure Practices of Insurance Companies in Bangladesh: Study on Some Selected Insurance Companies, the Cost and Management, ay-June, pp. 27-30.

Siddiquei, M. A. B. Neogy, T. K. and Islam, M. R. (2014), “Variations in Opinions toward Disclosure Trend of Insurance Companies in Bangladesh: An Empirical Study", American Journal of Trade and Policy, Vol. 1, No. 1, pp. 42-50.

Singhvi, S.S (1968), "Characteristics and Implication of Inadequate Disclosure: A Case Study of India". The International Journal of Accounting Education and Research, Vol. 3 No. 2 Spring, pp, 2944 